\title{
TOWARDS BUILDING A SEMANTIC FORMALIZATION OF (SMALL) HISTORICAL CENTRES.
}

\author{
M. Kokla ${ }^{1}$, M.A. Mostafavi ${ }^{2}$, F. Noardo ${ }^{3 *}$, A. Spanò ${ }^{4}$ \\ ${ }^{1}$ School of Rural and Surveying Engineering, National Technical University of Athens, Athens, Greece - mkokla@ survey.ntua.gr \\ ${ }^{2}$ Centre for research in Geomatics, Department of Geomatics Sciences, Université Laval Quebec, Canada - Mir- \\ Abolfazl.Mostafavi@scg.ulaval.ca \\ ${ }^{3}$ Department of Urbanism - Delft University of Technology, Delft, The Netherlands - f.noardo@tudelft.nl \\ ${ }^{4}$ Department of Architecture and Design (DAD) - Politecnico di Torino Viale Mattioli 39, 10125 Torino, Italy - \\ antonia.spano@polito.it
}

KEY WORDS: Semantic features, spatial objects, urban mapping, spatial reasoning, ontology, small historical urban centres

\begin{abstract}
:
Historical small urban centres are of increasing interest to different interacting fields such as architectural heritage protection and conservation, urban planning, disaster response, sustainable development and tourism. They are defined at different levels (international, national, regional), by various organizations and standards, incorporate numerous aspects (natural and built environment, infrastructures and open spaces, social, economic, and cultural processes, tangible and intangible heritage) and face various challenges (urbanization, globalization, mass tourism, climate change, etc.). However, their current specification within large-scale geospatial databases is similar to those of urban areas in a broad sense resulting in the loss of many aspects forming this multifaceted concept. The present study considers the available ontologies and data models, coming from various domains and having different granularities and levels of detail, to represent historical small urban centres information. The aim is to define the needs for extension and integration of them in order to develop a multidisciplinary, integrated semantic representation. Relevant conventions and other legislation documents, ontologies and standards for cultural heritage (CIDOC-CRM, CRMgeo, Getty Vocabularies), 3D city models (CityGML), building information models (IFC) and regional landscape plans are analysed to identify concepts, relations, and semantic features that could form a holistic semantic model of historical small urban centres.
\end{abstract}

\section{INTRODUCTION}

Historical small urban centres are of increasing interest for both the cultural heritage and landscape communities, and land planners. The historical small urban centres have often different configurations, regarding: physical morphology; extension; relationship with the road network; location in rural, hilly, mountainous and coastal areas; age of their settlement. Moreover, they are differentiated according to the different climatic bands.

The reflection on historical centers is the result of a very wide international debate closely intertwined with that on the cultural heritage that had culminating moments with the Washington charter (Washington Charter for the Conservation of Historic Towns and Urban Areas) and the Valletta Principles (ICOMOS 2011). Since the end of the 20th century such debate has benefited from reflections on cultural landscapes and cities as living assets, affirmed above all with the European landscape code (CoE, 2000) and with the UNESCO recommendation of 2011 (UNESCO 2011) upon the Historic Urban Landscape (HUL) that has the goal to integrate heritage conservation within the broader context of urban management.

The Historical Urban Landscape (HUL) approach is recognized as an innovative tool to preserve and manage heritage and historic cities. Member states are advised to adopt this approach in the application of local strategies and regulations, concerning the widespread territories, that allow for effective implementation. The HUL proposes a participatory use of planning so as to involve the communities and the many stakeholders in the decision-making process, especially taking into consideration the vulnerability in relation to the anthropogenic pressure and climate change, and above all to consider the integration of urban heritage values into broad urban development strategies.

Since these are very general considerations, but basic and underlying a new way of considering urban heritage, the opportunity "to undertake comprehensive surveys and mapping of the city's natural, cultural and human resources" is explicitly reported and specific implementation methods will have to be developed.

The semantic formalization of interrelated concepts could provide a common basis for identification, analysis, assessment and management of specific historical urban landscapes, taking into account all interacting factors. Ontologies are considered as conceptual structures for formalizing the explicit knowledge of a domain. They are particularly useful for capturing the semantics of complex, multidisciplinary concepts, their properties, and the intricate relationships between them.

Historical small urban centres and historical urban landscapes (containing them) are particularly pertinent notions for semantic formalization. They are defined at different levels (international, national, regional), by various organizations and standards, incorporate multifaceted aspects (natural and built environment, infrastructures and open spaces, social, economic, and cultural processes, tangible and intangible heritage) and face various challenges (urbanization, globalization, mass tourism, climate change, etc.).

The present paper analyses the concepts of historical small urban centres from different perspectives and levels of granularity. Although there is no existing ontology or standard that provides an integrated semantic formalization of small 
historical centres and their elements, there is a wealth of knowledge from conventions and other legislation documents, ontologies and standards for cultural heritage (CIDOC-CRM, CRMgeo, Getty Vocabularies), 3D city models (CityGML), building information models (IFC) and regional landscape plans that could provide the basis for developing a rich semantic formalization.

The remainder of this paper is as follows. Section 2 presents a review of the related work. Section 3 analyzes the proposed methodology, which converges in a more specific topic studied and discussed in Section 4. Section 5 presents the conclusions and future work.

\section{RELATED WORK AND AVAILABLE CONCEPTUALISATIONS}

Over the past few years, great efforts have been made to develop the conceptualization that starts from the historic urban landscape approach and involves fields of knowledge that before operated separately.

An interesting study by Ginzarly et al. (2018) tries to map the impact of the historic urban landscape approaches on the scientific community over the last ten years and adopting a data mining method to verify the amplitude in different sectors and its characters and different declensions.

A change in the landscape study, planning and management also resulted from considerations showing that whilst only the heritage of Roman antiquity assumed cultural value until the eighteenth century, the heritage spectrum was subsequently expanded from many points of view: chronological (from prehistory to the modern); typological (from the 'works of art' to rural, industrial heritage, etc.); geographical (from cities to the countryside and mountains); extension (from the single artifact to entire parts of cities and territory (Choay, 1992).

However, it is important to note the trends in the geographical information methods and tools for landscape management. A contribution to the comprehension of landscape values, considering the cultural heritage and the cities as sum of natural transformation, historical stratification of built environments and human activities, has derived from multitemporal geo-data hubs (Brumana et al. 2018, Previtali \& Latre, 2018).

It must be acknowledged that the whole debate on the landscape, which therefore goes beyond the affirmation of historic urban landscape, has already led to considerable renewals in the formulation of the regional landscape plans, which are taking new configurations in Italy (an example the one of the Piedmont Region, Cassatella \& Paludi eds 2018).

This shows how a technology pointing out the potential valuable features of a landscape, for example from the analysis of the existing maps or further available data, could effectively support the preservation and enhancement of such areas. The formal definition of the semantics ruling historical objects and sites can be very helpful in supporting preservation tasks, e.g. modelling of disappeared features or alternative scenarios (Liu et al., 2006; Liu et al., 2012; Apollonio et al., 2013), archaeological analysis (De Luca et al., 2011), landscape interpretation. On the other hand, a multidisciplinary, integrated formalization is crucial for bridging expertise within different interacting fields such as architectural heritage protection and conservation, urban planning, disaster response, sustainable development and tourism. Recent studies (Acierno et al. 2017) effectively modelled the architectural heritage knowledge in an ontology-based framework supporting conservation, also in connection with building information modelling (BIM) environment. A similar approach, which was never applied before, to the distributed heritage, like the small historical urban centres, would undoubtedly bring advantages to the considered historical urban landscapes, both by itself (i.e. including the formalized information in a wider knowledge context) and also in relation to the information concerning the smaller objects which are part of it (e.g. the historical buildings and other landmarks). For example, some of these take an increased cultural value (and connected vulnerability needs) by being part of such systems, even if they could not be worth by themselves. For this reason, it is important that the information concerning such complex kind of heritage is considered in the whole, as the study in this paper begins to explore.

\section{METHODOLOGY}

We propose to analyse the concepts of historical small urban centres from different perspectives and levels of detail in order to develop an integrated semantic representation of historical centers. As mentioned earlier, although there is no existing ontology or standard that provides a complete semantic formalization of small historical centres and their elements, there is a wealth of knowledge in terms of generic ontologies, standards, and legislation documents that could serve as a basis for development of a more adapted domain ontology for the exploration of historical small urban centres. For this purpose, we considered the analysis of conventions and legislation documents from UNESCO and ICOMOS, ontologies and standards for cultural heritage (CIDOC-CRM, CRMgeo, Getty Vocabularies), 3D city models (CityGML) as well as building information models (IFC) and regional landscape plans that could provide the basis for developing a richer and more granular semantic formalization. The choice of these sources is based on the fact that they provide the necessary concepts and definitions of urban centers and their components in different levels of detail and from different aspects. The present paper identifies concepts and definitions that are pertinent for the development of a domain/application ontology allowing better representation and exploitation of historical small centres information.

\subsection{Conventions and legislation documents from UNESCO and ICOMOS}

Major national and international organizations such as UNESCO focus on the protection, preservation, and enhancement of the world's cultural places. Charters, conventions, recommendations, and other formal documents provide wealth of knowledge on higher-level concepts, such as historic urban landscape, historic urban area, setting, landscape, built environment, etc.

In 2011, ICOMOS defined historic towns and urban areas as "spatial structures that express the evolution of a society and of its cultural identity. Historic sites are an integral part of a broader natural or man- made context and the two must be considered inseparable. Historical towns and urban areas are made up of tangible and intangible elements. The tangible elements include, in addition to the urban structure, architectural elements, the landscapes within and around the town, archaeological remains, panoramas, skylines, view- lines and landmark sites. Intangible elements include activities, symbolic and historical functions, cultural practices, traditions, memories, 
and cultural references that constitute the substance of their historic value".

In 2011, UNESCO adopted a new recommendation on Historic Urban Landscape (HUL) that includes new definitions, principles and guidelines for the conservation and development of urban heritage (UNESCO, 2011). The historic urban landscape is defined as "the urban area understood as the result of a historical layering of cultural and natural values and attributes, extending beyond the notion of 'historical centre' or 'ensemble'". This new broader notion includes an enriched definition of historical urban structures including the: "topography, geomorphology, hydrology and natural features; its built environment, both historic and contemporary; its infrastructures above and below ground; its open spaces and gardens, its land use patterns and spatial organization; perceptions and visual relationships; as well as all other elements of the urban structure. It also includes social and cultural practices and values, economic processes and the intangible dimensions of heritage as related to diversity and identity" (ibid.).

The analysis of these definitions reveals general concepts, properties, and relations that could constitute the higher level of an ontology for historic small urban centres. Figures 1 and 2 show the analysis and semantic formalization of the concept 'historic towns and urban areas' as defined by ICOMOS (2011) and 'historic urban landscape' as defined by UNESCO (2011) respectively.

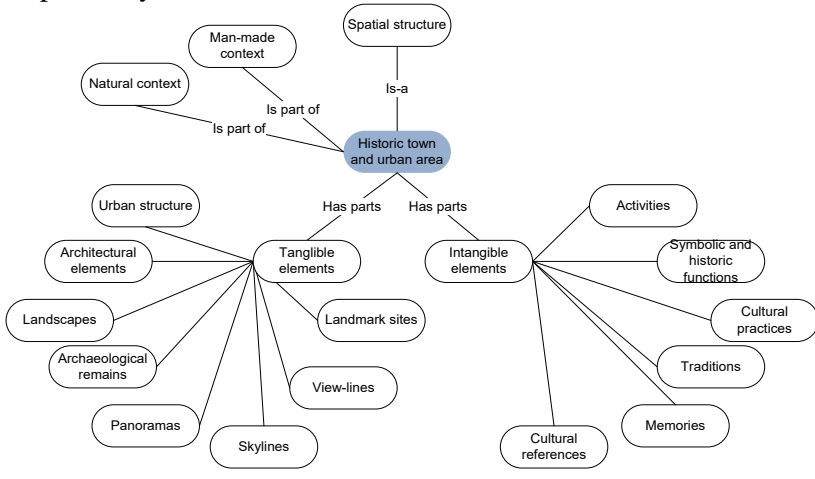

Figure 1. Semantic formalization of the concept 'historic towns and urban areas' as defined by ICOMOS (2011).

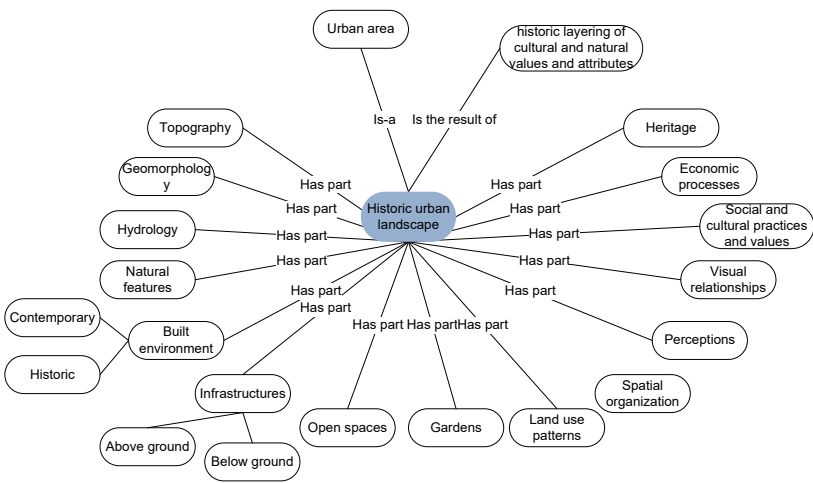

Figure 2. Semantic formalization of the concept 'historic urban landscape' as defined by ICOMOS (2011).

\subsection{Standard vocabularies and ontologies for Cultural Heritage: Getty Vocabularies and CIDOC-CRM}

The core ontology for managing cultural heritage information, now standard ISO 21127, was developed by the International Committee for Documentation (CIDOC) of the International Council of Monuments (ICOM). It is the 'CIDOC conceptual reference model' (CIDOC-CRM) (Doerr et al., 2007). Even if it was initially addressed to the representation of museums objects knowledge, it structures high-level concepts, so that it can be effectively applied to connected fields, included architectural heritage and heritage landscapes. For structuring the concepts and relationships (including meronomy and topology) involved in the 'small centres' ontology, the CIDOC-CRM can play an important role. In Figure 3 it is possible to see an overview of the most important concepts which can be used to model the information about the location of objects. The part-of relationships can instead be represented through the entities represented in Figure 4.

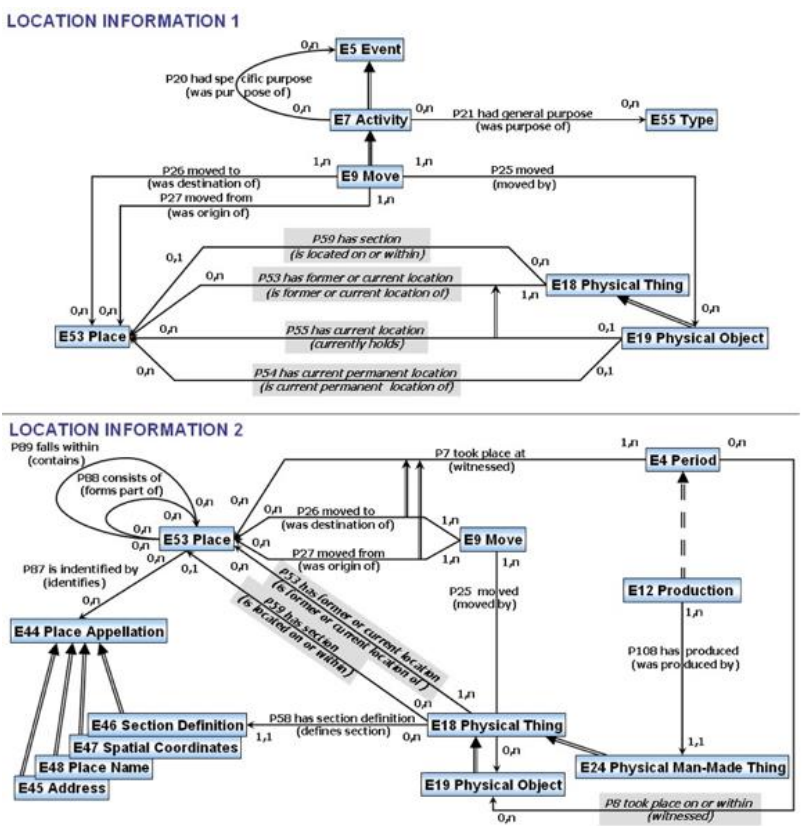

Figure 3. Conceptual representation of the location information according to the CIDOC-CRM (image from http://www.cidoccrm.org/FunctionalUnits/location-information).

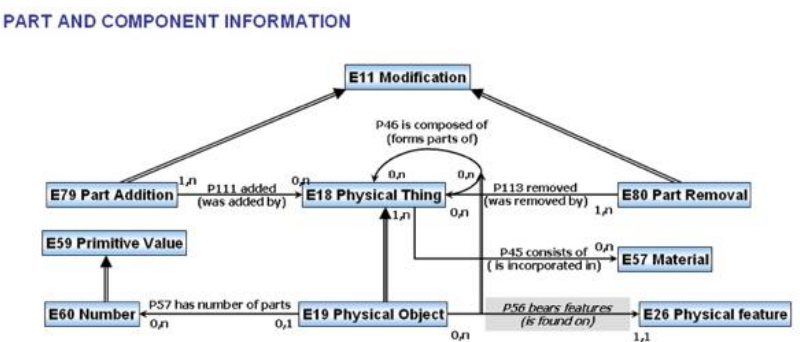

Figure 4. Conceptual representation of the part and component information according to the CIDOC-CRM (image from http://www.cidoc-crm.org/FunctionalUnits/part-andcomponent-information).

The developed extensions to the CIDOC-CRM could be considered in addition, especially when structuring the higher level of detail objects (the single window, the single building element). In particular, the 'CRMba', for the documentation of 
standing buildings (Ronzino et al., 2015) and CRMgeo (Doerr et al., 2013), permitting the inclusion of spatial information through the use of geoSPARQL language, could be the most interesting.

The advantage given by the compliancy of the ontology with the CIDOC-CRM also consists in the enhanced possibility to retrieve useful datasets in the already shared information on the web. For example, the ARCHES project (Myers et al., 2013), by the Getty Conservation Institute (http://www.getty.edu) and the World Monuments Fund (https://www.wmf.org/), developed an open source, interoperable, web- and geospatially based information system for inventory and management of immovable cultural heritage, structured following the CIDOCCRM, with a connected webGIS. It allows the representation of a simple 2D geometry on a base map, without complex 3D features. However, this could be sufficient to provide datasets for a small-scale analysis (limited to two dimensions) of the small historical centres landscape.

Another important reference for classifying the cultural heritage related information are the vocabularies developed by the Getty Institute (http://vocab.getty.edu/), to structure terms and items: the Art and Architecture Thesaurus (AAT), structuring terms linked to the description of works of art and architectures; the Thesaurus of Geographic Names (TGN), which, in contrast to GeoNames (structured database for toponyms) (http://www.geonames.org/), also includes historical denominations; the Union List of Artist Names (ULAN), containing names and synthetic information about $\mathrm{CH}$ authors; and the Cultural Objects Name Authority (CONA), describing the different denominations of a cultural item over time. They represent a very important reference for the classification of concepts involved in the heritage landscapes knowledge, some of which have a spatial connotation (e.g. architectural parts, kinds of buildings, urban spaces, toponyms and so on) or for related information (authors, objects names, artistic movements).

The Getty vocabulary has a very high granularity in the definition of included terms and even the smallest elements can be classified according to the listed hierarchical categories. However, no connections relate each term to a spatial connotation. Therefore, it is a very rich source of concepts and an important reference for cultural heritage-related terms, but it is not sufficient to completely represent the topic.

\subsection{Interrelated domains and their semantics: 3D city models (CityGML) and Building Information Models (IFC).}

Buildings are important parts of the landscapes themselves and are composed of specific and characteristic elements. Hence, they are the necessary starting point for the ontological definition of small historical centres. Outside the cultural heritage field, other data models are currently used to structure the buildings-related information. For representing buildings as well as other elements of a landscape, it is necessary to consider the open standards for digital (3D) maps. In particular, the most internationally accepted standard is CityGML, prompted by the Open Geospatial Consortium (OGC). It is aimed at the interoperable archiving and representation of 3D city objects in multiple levels of detail. Some application domain extensions of CityGML (Biljecki et al., 2018) for representing more suitably cultural and architectural heritage features and specific connected use cases were proposed (Noardo, 2018; Zalamea Patiño et al., 2016; Egusquiza Ortega , 2015; Costamagna, Spanó, 2013). Most of these extensions add specific building- features, increasing the semantic information foreseen by CityGML for heritage-specific needs.

Another model which could be effectively considered when representing landscape information was developed within the 'INfrastructure for Spatial InfoRmation in Europe' (INSPIRE) European Directive (INSPIRE, 2007). The INSPIRE data model is conceived for representing even wider portions of land, since it is aimed at a cross-boundary representation of maps, to be support to environmental policies in Europe. However, many entities included in the model can be useful for heritage landscapes representation (e.g. Protected Site, Area Management Restrictions, and so on) besides Buildings and other classes describing landscape features (roads, water, vegetation, and so on $)^{1}$. In the INSPIRE data model, the representation of some kind of heritage (e.g. UNESCO) is already included. However, some studies exist, also in this case, to extend the model with a higher level of detail in the description (Fernández-Freire et al., 2013; Colucci et al., 2018; Chiabrando et al., 2018).

For the purpose of this paper, some specific features of (City)GML enabling topological relationships archiving and analysis are very useful (Salleh and Ujang, 2018; Li et al., 2016). They can allow both the archiving of the found information as part of the existing digital maps, and the use of these ones, in turn, as an input data to be analysed in the light of such patterns.

On the other hand, different models are developed and used for designing and enabling buildings construction by generally allowing higher levels of details. The Building Information Models (BIMs) are used for these aims. They store mainly solids (usually parametrically modelled), are usually modelled in a local reference system, and structure their information through the Industry Foundation Classes (IFC) open standard, by buildingSMART ${ }^{2}$. In this case, the most general entity is 'IFCSite', representing the area where the new building should be designed and constructed. 'IFCBuilding' follows in the hierarchy, and the building is then decomposed in all its smaller components, including railings and pipes, and so on. The entities included in the IFC model are intended for newly designed buildings, therefore they are not always suitable to represent historical building features.

In recent years more efforts have been made to enhance the semantics of 'Historical BIMs' (HBIMs) with a heritage-related semantics (Quattrini et al., 2017; Diara, Rinaudo, 2018). Here in this paper, we propose to map the 'small historical centres' ontology entities to this open data model to better exploit available historical information. A HBIM could be worth to be analysed through the 'small historical centres' ontology approach when going to higher levels of detail, so that the importance of each building element can be considered in defining the semantic identity of the whole building (e.g. windows shape, floor heights, used materials, roof shape and so on). This, in turn, will shape the considered historic urban landscape. The HBIM approach is becoming increasingly important in the cultural heritage and preservation field (Hichri et al., 2013; Oreni et al, 2013;), so that many datasets will be available in future. This will be especially effective when using integrated geoinformation with BIM (GeoBIM), for which

\footnotetext{
1 https://inspire.ec.europa.eu/data-model/approved/r4618$\mathrm{ir} / \mathrm{html} /$

https://www.buildingsmart.org/about/what-is-openbim/ifc-
} introduction/ 
many studies are being developed (Zhu et al., 2018; Ellul et al., 2018; Ohori et al., 2018).

\section{NARROWING DOWN THE DOMAIN: FORTIFIED CITIES}

For the definition of the landscape plans it is known that the reading of the historical landscape and of the characteristics of the settlement stratified over the centuries, requires both overall visions (small scale maps) as well as detailed readings on the cultural heritage (large scale/urban scale maps, architectural scale models and drawings). In the recent past, landscape plans and historical landscape atlas have been structured as a collection of objects recognized in the territory, and now the relevant innovation is to recognize that the historical landscape is a system of territorial relations, subject to continual transformation processes, that are responsible of the degree of conservation and susceptible to change (Longhi, Volpiano 2018).

The new interpretation of the historical settlement structure and of the heritage urban landscape is more complex and deep. The 'historical settlement structure of centres with strong morphological identity' can be further categorized (Longhi, Volpiano 2018) as:

Archaeological permanencies (remains) of Roman foundations;

Isolated structures witnessing of transfers and residential abandonments, in turn:

- military structures (outcome of fortification);

- religious structures (outcome of a plebeian organization medioeval settlement);

Settlements of new foundation or re-foundation in the Middle Ages (Villenove, shelters);

Settlements with noble and / or military structures that characterize their identity and morphology;

Settlements with religious structures characterizing identity and morphology;

Settlements characterized mainly by re-foundation or relevant urban transformations of the modern age. Territorial arrangement in absolutism age.

Settlements characterized by re-foundation or major urban transformations of contemporary age. Urban systems / complexes of arch. of the Modern and according to the twentieth century.

As an illustration, in this paper we have decided to develop a more specific semantic formalisation concerning the type of cities strongly characterised by fortifications, which are very common in several countries. Very often the analysed small historical centres are built inside the original city walls and the defensive structure is still apparent, even if merged into the following structures. With this step we aim at adding granularity to the UNESCO and ICOMOS conceptualisations (Figures 1 and 2) useful to the specific representation of fortified small cities.

\subsection{Involved terms}

We can start to analyse the theme of the 'fortification' or 'fortified urban centres' considering that, adding to castle, there are many concepts that can be represented by a geometrical object in the map. Some of them are: fortification, rampart, city wall, bastion, urban walls, bulwark, city gate, moat (now they are roads), urban gate, gate tower, tower, merlon, castrum (castra), battlements, fort, crenellated (tower, bridge ect.), embankment (terreplain), citadel. The hierarchy of connected terms in the Getty AAT classification is represented in Figure 5.

\subsection{An example - the city of Norcia}

For connecting our conceptualisation to actual examples, we looked at many similar urban centres. We present here Norcia as a topical case for historical small centres strongly characterized by fortification schemas and structures. Norcia is a historical centre in central Italy, founded in the 5th century bC by a pre-Roman population (Sabini) and conquered by the Romans in the 3rd century, it was subordinated to the papal dominion in the Middle Ages and was also subject to recurrent earthquakes, sometimes devastating. The city lived in the seventeenth century a period of cultural prosperity and today, despite the urban reorganization of the nineteenth century, it appears as a walled centre, as can be immediately observed in the aerial DSM and orthophoto (Figures 6 and 7). The city wall for long stretches is incorporated into the buildings and a ringshaped street surrounds the walls. In the central square, which is overlooked by historic buildings including the church of San Benedetto sadly collapsed in 2016, there is also a fortified Renaissance palace (which is different from a castle in a historical semantic perspective). The most common structures included in such kind of centres are clearly identifiable in city buildings and urban texture (Figure 6).

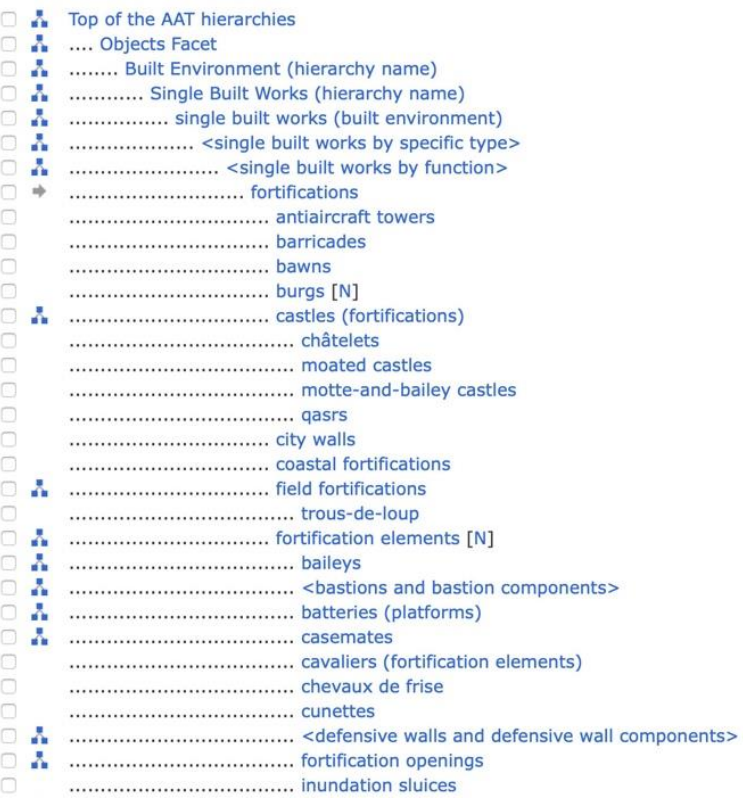

Figure 5. An extract of the Getty AAT vocabulary hierarchy related to the term 'fortification'.

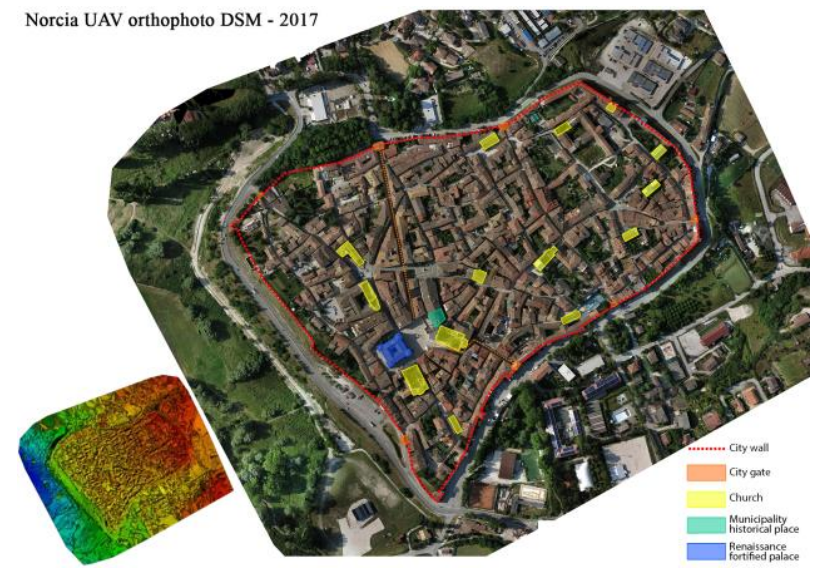


Figure 6. UAV Orthophoto (Geomatics LAB -Politecnico di Torino) with location of the city wall-related structures.

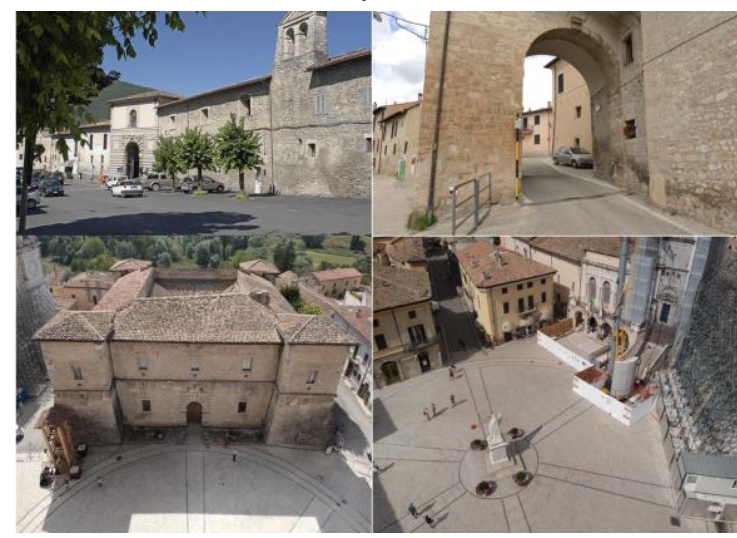

Figure 7. Some views of Norcia: the Ascolana gate, a small gate in the west side of the city wall, the fortified palace, the Saint Benedetto central square (patron of Europe).

\subsection{Analysis of the Norcia example in available official map}

The question to be asked is what tools do we have using the basic available maps to analyze such historical sites? As mentioned earlier, generic geographic information systems do not include specific terms allowing the exploitation of historical information. However, more recent versions of the content specification of the Italian geographical databases foresee codes to enrich the domain of building typology. For instance, in addition to the general category as generic building, it proposes more specific terms, such as: 'tower palace', 'skyscraper', 'villa', 'terraced house', 'baptistery', 'bell tower', 'belfry', 'warehouse', 'rural building', 'castle', 'church', 'amphitheatre', 'lighthouse', 'hangar', 'minaret', 'mosque', 'temple', 'mill', 'observatory', 'sports hall'. Furthermore, the terms identifying some local typical buildings (whose name cannot be translated) are included ('nuraghe', 'dammuso', 'tabià', 'masseria', 'trullo', 'barchessa', and so on).

In the available map of Norcia, the building layer is derived from 1:2000 scale cadastre dataset, with parcels code and an attribute declaring the state of conservation (each building, even the renaissance palace, or the saint Benedetto basilica, the city gates etc.). In addition, the city wall, when not incorporated into the buildings is classified as 'retaining wall' pertaining the macro-class of 'supporting structure pertaining the soil protection'. The concept of city wall is defined as follows: "objects that constitute forms of control and adaptation of the orography in order to make the territory compliant and safe for human activity".

However, no coherent use of such term can be found in similar contexts (for example, the same attribute code is used for the surviving bastions of the walls of Turin in the urban scale (1:1000) database map). On the other hand, the encoding of the Turin ramparts in the updated regional database maps (called 'BD3'), the preserved bastions are classified as 'wall or division in thickness', pertaining the macro class 'manufactured structures'. If we observe another site, the Alessandria citadel in Piedmont, which is the largest preserved citadel in Europe, object of many historical inquiries, we find the same optimization of semantic field. The latter has the definition: "all those objects in support of road works, water works, buildings, etc. that are realized through human labor". The further classification in specific classes derives both from functional considerations and from the geometric behavior of the artefacts to vary the scale which is closer to the current knowledge domain of historical structures.

\subsection{One representative concept}

Considered the complexity of the available data and used conceptualisations, we tried to make a step forward integration and development of a suitable ontology by investigating specifically one concept in more detail. Table 1 illustrates the presence of the concept 'City wall' in different ontologies. As we can see from the table, this concept is only explicitly present in the AAT Getty vocabulary. We can also see that there are several possibilities of mapping this concept to the existing entities and classes in each of the mentioned ontologies that adds to the complexity of exploration of its information using those ontologies. We can conclude from this simple case that the existing sources do not provide the necessary tools that allow us to manage historical heritage information meeting the expectations and needs of the cultural heritage, landscape as well as land planners communities for assessment and management of specific historical urban landscapes.

Table 1: Representation of the concept 'City walls' in different ontologies

\begin{tabular}{|c|c|c|c|}
\hline Ont. & $\begin{array}{l}\text { Explicit } \\
\text { concept }\end{array}$ & Related concepts and hierarchy & Remarks \\
\hline 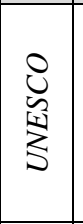 & no & $\begin{array}{l}\text { Historic built landscape } \rightarrow \text { built } \\
\text { environment } \rightarrow \text { historic }\end{array}$ & $\begin{array}{l}\text { - The concept of 'City wall' does not exist explicitly } \\
\text { - global ontology } \\
\text { - many concepts could include city walls in their sub concepts, } \\
\text { but not sufficient granularity is present } \\
\text { - no location information } \\
\text { - no formal representation }\end{array}$ \\
\hline 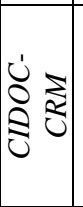 & no & $\begin{array}{l}\text { Entity } \rightarrow \text { Persistent item } \rightarrow \text { thing } \rightarrow \\
\text { Man-Made Thing } \rightarrow \text { Physical Man-Made } \\
\text { Thing } \rightarrow \text { Man-Made Object } \\
\text { Man-Made Thing } \rightarrow \text { Physical Man-Made } \\
\text { Thing } \rightarrow \text { Man-Made Object }\end{array}$ & $\begin{array}{l}\text { The concept of 'City wall' does not exist explicitly } \\
\text {-domain ontology (core ontology) } \\
\text { - more detailed levels of concepts and relations } \\
\text { - location is included in the ontology } \\
\text { - formally represented }\end{array}$ \\
\hline
\end{tabular}




\begin{tabular}{|c|c|c|c|}
\hline 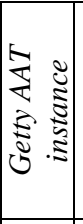 & City wall & $\begin{array}{l}\text { Built environment, single built } \\
\text { environment, ..., fortification, city wall } \\
\text { (See Figure 5) }\end{array}$ & $\begin{array}{l}\text { the concept of 'City wall' does exist explicitly } \\
\text { - Thesaurus } \\
\text { - high granularity } \\
\text { - location is not included } \\
\text { - formally represented } \\
\text { - a definition is given: "Fortification walls of cities" }\end{array}$ \\
\hline$\underset{:}{\stackrel{\Xi}{:}}$ & $\begin{array}{l}\text { not intended as } \\
\text { heritage artifact }\end{array}$ & $\begin{array}{l}\text { CityObject } \rightarrow \text { Site } \rightarrow \text { AbstractBuilding } \rightarrow \\
\text { Building } \\
\text { CityObject } \rightarrow \text { Site } \rightarrow \text { AbstractBuilding } \rightarrow \\
\text { Building Part }\end{array}$ & $\begin{array}{l}\text { The surface used to represent the object can be further specified } \\
\text { as 'Wall Surface'. } \\
\text { These entities are not intended for representing heritage objects } \\
\text { explicitly. } \\
\text {-formally represented (GML/XSD encoding) }\end{array}$ \\
\hline 过 & $\begin{array}{l}\text { not intended as } \\
\text { heritage artifact }\end{array}$ & $\begin{array}{l}\text { IfcSite } \rightarrow \text { IfcBuilding } \\
\text { IfcSite } \rightarrow \text { IfcBuilding } \rightarrow \text { IfcWall }\end{array}$ & $\begin{array}{l}\text { Historical fortification connotation of city wall is missing. } \\
\text { Both IfcBuilding and IfcWall can be used to represent 'city wall'. } \\
\text { The ontology is intended for building elements (very high level } \\
\text { of detail) } \\
\text {-formally represented (STEP/EXPRESS encoding) }\end{array}$ \\
\hline
\end{tabular}

\section{CONCLUSIONS}

In this paper we highlighted the importance of historical small urban centers and the increasing interest for the cultural heritage, landscape as well as land planners' communities for better identification, analysis, assessment and management of specific historical urban landscapes. We argued that semantic formalization of interrelated concepts used in those communities can provide a common basis for such purposes. Ontologies are considered as conceptual structures for formalizing the explicit knowledge of a domain. They are particularly useful for capturing the semantics of complex concepts and their relations.

In order to provide the necessary basis for understanding diverse challenges that need to be addressed for defining a common ontology that allows the representation of small historical centers, we proposed to analyse several existing sources that partially addresses this domain of interest. More specifically we considered conventions and legislation documents provided by UNESCO and ICOMOS, as well as the ontology for cultural heritage CIDOC-CRM, Getty Vocabularies, 3D city models (CityGML), and building information models (IFC).

A close analysis of these sources revealed that they are generally not adapted for adequate representation of the information of historical landscapes because for example UNESCO and ICOMOS documents provide definitions of some historical heritage related concepts in a non-formal way. CIDOC-CRM goes to more detailed semantic representation of historical heritage concepts but still, it misses characterizing aspects of these concepts in terms of geometry and shape. Getty Vocabulary in its turn focus on the vocabulary itself, without spatial aspects and complex concepts relationships. CityGML and IFC are formal ontologies that are very interesting in terms of the treatment of very detailed level of concepts related to urban environment and buildings however they are not adapted to represent and characterize explicitly the concepts related to historical sites.

In order to illustrate these challenges, we have presented an example for detecting and exploring information on a specific concept 'City wall'. We noted that this concept was generally absent in those ontologies except in Getty vocabulary. We also noted that it is very complex to define a clear relation between this concept with other existing concepts defined in the mentioned ontologies. The heterogeneity of concepts and relations as defined by these ontologies complicates their common use by cultural heritage, landscape as well as land planners' communities.

To overcome these complexities, we plan to push forward our investigation towards the development of a domain ontology for the exploration and analysis of historical heritage information at different levels of granularity. This ontology should also provide enough tools for the detection of historical sites and buildings from increasingly available geospatial data through new technologies such as LiDAR data, UAV acquired data and more.

\section{REFERENCES}

Acierno, M., Cursi, S., Simeone, D., \& Fiorani, D. (2017). Architectural heritage knowledge modelling: an ontologybased framework for conservation process. Journal of Cultural Heritage, 24, 124-133.

Apollonio, F. I., Gaiani, M., \& Sun, Z. (2013). 3D modeling and data enrichment in digital reconstruction of architectural heritage. ISPRS Archives, 5, W2.

Biljecki, F., Kumar, K., \& Nagel, C. (2018). CityGML Application Domain Extension (ADE): Overview of developments. Open Geospatial Data, Software and Standards, 3(1), 13.

Brumana, R., Oreni, D., Caspani, S., Previtali, M., Virtual museums and built environment: Narratives and immersive experience via multi-temporal geodata hub (2018) Virtual Archaeology Review, 9 (19), pp. 34-49

Cassatella C., Paludi G., eds, 2018, Il Piano paesaggistico del Piemonte The Landscape Plan of Piedmont Region, A\&RT, LXXII - N. 3

Chiabrando, F.; Colucci, E.; Lingua, A.; Matrone, F.; Noardo, F.; Spanò, A, 2018. A European interoperable database (EID) to increase resilience of cultural heritage. In: Archives of ISPRS. - ISSN 1682-1750. 42(2018), pp. 151158.

Choay F., 1992, L'Allégorie du patrimoine, Seuil, Paris.

CoE. 2000. "European Landscape Convention." Florence, Council of Europe. Accessed 15 december 2018. http://conventions.coe.int/Treaty/en/Treaties/Html/176.htm. 
Colucci, E., Noardo, F., Matrone, F., Spanò, A., \& Lingua, A. (2018). High-Level-Of-Detail Semantic 3D GIS for Risk and Damage Representation of Architectural Heritage. International Archives of the Photogrammetry, Remote Sensing \& Spatial Information Sciences.

Costamagna E, Spanò A. CityGML for Architectural Heritage. In: Developments in Multidimensional Spatial Data Models. Berlin, Heidelberg: Springer: 2013. p. 219-237.

De Luca L., C. Busarayat, C. Stefani, P. Veron, M. Florenzano, A semantic-based platform for the digital analysis of the architectural heritage, Comput. Graph. 35 (2) (2011) 227-241.

Diara, F., \& Rinaudo, F. (2018). OPEN SOURCE HBIM FOR CULTURAL HERITAGE: A PROJECT PROPOSAL. International Archives of the Photogrammetry, Remote Sensing \& Spatial Information Sciences, 42(2).

Doerr, M., Ore, Ch.E., Stead, S., 2007. The CIDOC Conceptual Reference Model - A New Standard for Knowledge Sharing. In: Tutorials, posters, panels and industrial contributions at the 26th International Conference on Conceptual Modeling. ACS. 83. pp. 51-56.

Doerr M., G. Hiebel, Ø. Eide, CRMgeo: Linking the CIDOC CRM to geoSPARQL through a Spatiotemporal Refinement. Tech. Rep. GR70013, Institute of Computer Science, 2013.

Egusquiza Ortega A Multiscale information management for historic districts' energy retrofitting: a framework, a methodology, a model. PhD thesis. 2015.

Ellul, C., Stoter, J. E., Harrie, L., Shariat, M., Behan, A., \& Pla, M. (2018). Investigating the state of play of geoBIM across Europe.

Fernández-Freire, C., del-Bosque-González, I., VicentGarcía, J. M., Pérez-Asensio, E., Fraguas-Bravo, A., UriarteGonzález, A., Fábrega-Álvarez P., Parcero-Oubiña, C., 2013. A Cultural Heritage Application Schema: Achieving Interoperability of Cultural Heritage Data in INSPIRE. IJSDIR, 8, pp. 74-97.

Getty ARCHES Project, http://archesproject.org, http://www.getty.edu/ conservation/our projects/field projects/arches/arches overview.html (accessed 12.05.17).

Getty Institute, http://www.getty.edu (accessed 12.05.17).

Getty Vocabularies, http://vocab.getty.edu/ (accessed 12.05.17).

Geonames, http://www.geonames.org/ (accessed 12.05.17).

Hichri, N. Stefani C., De Luca L., Veron P., Hamon G., From point cloud to BIM: a survey of existing approaches, ISPRS Int. Arch. Photogramm. Remote Sens. Spat. Inf. Sci. 1 (2) (2013) 343-348.

ICOMOS. 1987. "Charter for the Conservation of Historic Towns and Urban Areas - Washington Charter." ICOMOS. Accessed 15 December 2018. https://www.icomos.org/en/what-we-do/focus/179-articlesenfrancais/ressources/charters-and-standards/159-charter-forthe-conservation-of-historic-towns-and-urban-areas.

ICOMOS. 2011. "The Valletta Principles for the Safeguarding and Management of Historic Cities, Towns and Urban Areas Principles De La Valette Po." ICOMOS. $\begin{array}{llll}\text { Accessed } & 15 & \text { December } & 2018 .\end{array}$
http://www.international.icomos.org/Paris2011/GA2011_CI VVIH_text_EN_FR_final_20120110.pdf.

INSPIRE European Directive 'INfrastructure for Spatial InfoRmation in Europe' (INSPIRE), European Directive Developed by the European Parliament and the Council on the 14th of March, 2007 (Directive 2007/2/EC), http://inspire.ec.europa.eu/ (accessed 11/03/2019).

Ginzarly, M., Houbart, C., \& Teller, J. (2018). The Historic Urban Landscape approach to urban management: a systematic review. International Journal of Heritage Studies. doi: 10.1080/13527258.2018.1552615

Previtali, M. \& Latre, M.Á., A brokered Virtual Hub approach for the generation of web applications based on historical maps, Appl Geomat (2018) 10: 453. https://doi.org/10.1007/s12518-018-0235-1

buildingSMART, https://www.buildingsmart.org/about/whatis-openbim/ifc-introduction/ Accessed on 11/03/2019.

INSPIRE data model. https://inspire.ec.europa.eu/datamodel/approved/r4618-ir/html/ Accessed on 11/03/2019.

CIDOC-CRM.

http://www.cidoc-

crm.org/FunctionalUnits/part-and-component-information Accessed on 11/03/2019.

Liu, Y., Xu, C., Pan, Z., \& Pan, Y. (2006). Semantic modeling for ancient architecture of digital heritage. Computers \& Graphics, 30(5), 800-814.

Liu, Y., Mingmin, Z., Yunliang, J., \& Haiying, Z. (2012). Improving procedural modeling with semantics in digital architectural heritage. Computers \& Graphics, 36(3), 178184.

Li, L., Luo, F., Zhu, H., Ying, S., \& Zhao, Z. (2016). A twolevel topological model for 3D features in CityGML. Computers, Environment and Urban Systems, 59, 11-24.

Myers D., Y. Avramides, A. Dalgity, Changing the heritage inventory paradigm, the ARCHES open source system, Conserv. Perspect. GCI Newsl. 28 (2) (2013).

Noardo F. Architectural heritage semantic 3D documentation in multi-scale standard maps. J Cult Herit. 2018; 32:156-65.

Ohori, K., Diakité, A., Krijnen, T., Ledoux, H., \& Stoter, J. (2018). Processing BIM and GIS models in practice: experiences and recommendations from a GeoBIM project in The Netherlands. ISPRS International Journal of GeoInformation, 7(8), 311.

Oreni, D., Brumana, R., Georgopoulos, A., \& Cuca, B. (2013). HBIM for conservation and management of built heritage: Towards a library of vaults and wooden bean floors. ISPRS Annals of Photogrammetry, Remote Sensing and Spatial Information Sciences, 5, W1.

Quattrini, R., Pierdicca, R., \& Morbidoni, C. (2017). Knowledge-based data enrichment for HBIM: Exploring high-quality models using the semantic-web. Journal of Cultural Heritage, 28, 129-139.

Ronzino P., F. Niccolucci, A. Felicetti, M. Doerr, CRMba a CRM extension for the documentation of standing buildings, Int. J. Digit. Libr. (2015) 1-8.

Salleh, S., \& Ujang, U. (2018, June). Topological information extraction from buildings in CityGML. In IOP Conference Series: Earth and Environmental Science (Vol. 169, No. 1, p. 012088). IOP Publishing. 
UNESCO. 2011. Recommendation on the Historic Urban Landscape. Paris: UNESCO World Heritage Centre. Accessed $\quad 15 \quad$ December 2018. https://whc.unesco.org/uploads/activities/documents/activity638-98.pdf

Zalamea Patiño O, Van Orshoven J, Steenberghen T. From a citygml to an ontology-based approach to support preventive conservation of built cultural heritage. In: Proceedings of the 19th AGILE International Conference on Geographic Information Science: 2016.

Zhu, J., Wright, G., Wang, J., \& Wang, X. (2018). A critical review of the integration of geographic information system and building information modelling at the data level. ISPRS International Journal of Geo-Information, 7(2), 66. 